\title{
United Nations against CBW
}

The United Nations Expert Committee on Chemical and Bacteriological Weapons has come out with as strong a condemnation of these potential agents of modern warfare as any to have been published in the past few months. One of its particular contributions to the public discussion of chemical and biological weapons is its warning that the large scale use of chemical and biological weapons in war could lead to permanent ramage to the environment. "No one could predict how enduring the effects would be, and how they would affect the structure of society and the environment in which we live. This overriding danger would apply as much to the country which initiated the use of these weapons as to the one which had been attacked, regardless of what protective measures it might have taken in parallel with its offensive capability."

The Expert Committee was set up by the secretarygeneral of the United Nations in response to a resolution of the last General Assembly in 1968. It consisted of fourteen consultants, many of them public servants but required for the purposes of the study to act in a personal capacity. The secretary-general says in his introduction to the report that he accepts it "in its entirety and that he would like to see more states acceding to the Geneva protocol of 1925, that he would like the signatories of the protocol to agree that the prohibition applies even to agents such as tear gas and that there should now be an agreement to halt "the development, production and stockpiling" of all biological weapons. In Geneva on July 10, Mr Fred Mulley, speaking for the British Government, argued that the second of the proposals would not be acceptable, chiefly on the grounds that several countries have come to rely on agents similar to tear gas for the control of civil disorders.

The committee states that its object has been to identify the likely effects of the use of chemical and biological weapons. In general, it says that they are distinguished by their variability and even unpredictability, and by the way in which civilians are more at risk than the military. Protection, the argument goes, would be costly and "all but impossible" from an administrative point of view. And even if military personnel were somehow able to escape the immediate effects by being protected, they would not escape tho widespread and long-term effects which the weapons could cause. Finally, the committee argues, escalation is a particular danger with chemical and biological weapons.

The committee says that the technological problems of chemical and biological weapon production are not so great that a nation with "well advanced" chemical, pharmaceutical and fermentation industries would be incapable of manufacturing them. But there are problems of safety, chemical synthesis and delivery systems as well as the need, particularly with biological weapons, to ensure that the agents remain viable. By contrast, the problems of defence are more difficult-alarm systems against chemical attack, for example, "are very complex electromechanical devices whose production demands a highly technologically based industry".

The committee retails an interesting case of an experiment to assess the feasibility of disseminating bacteriological agents. The harmless powder zinc cadmium sulphide was released in the form of two micron particles from a ship at sea. Some 200 kilograms was released on a course parallel to the coastline and 260 kilometres long. 'The report says that the material travelled at least 750 kilometres and covered an area of more than 75,000 square kilometres. Even allowing for the decay of the viability of real infectious bacteriological particles in passage through the atmosphere, the committee considers that an area of between 5,000 and 20,000 square kilometres could have been attacked, and that the downwind risk associated with the operation would have been negligible. Covert attack could be even more effective-half a kilogram of a culture of Salmonella could poison a reservoir containing 5 million litres of water.

Although the biological agents considered as potential weapons are usually the causes of known diseases, the report says that their effects could be more severe when they are used as aerosol weapons, chiefly because of the variability of resistance, among human populations. Thus weapons designed to incapacitate could be lethal against a population undermined by malnutrition. The committee's list of organisms includes the suggestion that genetic selection could be made to yield more virulent and stable strains of known viruses, that rickettsiae are comparatively poorly known, that strains of bacteria resistant to an antibiotic as well as to sunlight and drying could be selected, that fungi have little promise as biological weapons as have protozoa (which are too complex) and parasitic worms (which are too slow). 'The report points out that biological attack against animals might often be more effective than attack against human populations, and that plant pathogens could be used for military purposes if there were sufficient amounts of the relevant host plant in the regions to be attacked and if geographical circumstances were suitable for the spread of infection. On methods of protection, the Expert Committee says that antidotes to nerve gases (such as atropine) can be valuable within a very short time of exposure, but are not without their side effects. Vaccination is unlikely to be effective for whole populations, partly because of the difficulty and cost of a thorough vaccination programme and the problem of predicting what materials must be protected against. Antisera against all possible biological agents could not be manufactured, while the use of antibiotics would have very little value if the user of the weapons knew about antibiotic resistant strains.

The report is weak on detection and warning. The problem, it says, is determined by the fact that a person breathes in between 10 and 20 litres of air a minute. Warning devices consist of air sampling instruments and area survey instruments, and the latter have the advantage of being independent of the wind. One of the problems with biological weapons is the way in which they merge into the background in suitable circumstances.

The report has some detailed information about the efficacy of various nerve agents, the most toxic of which cause death at a dose of $10 \mathrm{mg} \mathrm{min} / \mathrm{m}^{3}$. (See Table 1.) Mustard gas and the more recently developed vesicants can produce irritation and even blindness at 


\begin{tabular}{|c|c|c|c|c|c|c|c|}
\hline Agent & Sarin & $\begin{array}{l}\text { able 1. CHEMICAI } \\
\text { VX }\end{array}$ & $\begin{array}{l}\text { PROPERTIES, FORMUL } \\
\text { Hydrogen cyanide }\end{array}$ & $\begin{array}{l}\text { ITIONS AND TOXICXTIES } \\
\text { Cyanogen chloride }\end{array}$ & $\begin{array}{l}\text { S OF LETHAL CHEMICA } \\
\text { Phosgene }\end{array}$ & $\begin{array}{l}\text { AL AGENTS } \\
\text { Mustard gas* }\end{array}$ & $\begin{array}{c}\text { Botulinal } \\
\text { toxill A }\end{array}$ \\
\hline Nature & $\begin{array}{l}\text { Lethal agent } \\
\text { (nerve gas) }\end{array}$ & $\begin{array}{l}\text { Lethal agent } \\
\text { (nerve gas) }\end{array}$ & $\begin{array}{l}\text { Lethal agent } \\
\text { (blood gas) }\end{array}$ & $\begin{array}{l}\text { Lethal agent } \\
\text { (blood gas) }\end{array}$ & $\begin{array}{l}\text { Lethal agent } \\
\text { (lung irritant) }\end{array}$ & $\begin{array}{c}\text { Lethal agent } \\
\text { (vesicant) }\end{array}$ & Lethal agent \\
\hline $\begin{array}{l}\text { Solubility } \\
\text { in water }\end{array}$ & 100 per cent & $1-5$ per cent & 100 per cent & 6-7 per cent & Hydrolysed & 0.05 per cent & soluble \\
\hline $\begin{array}{l}\text { Volatility } \\
\left(20^{\circ} \mathrm{C}\right)\end{array}$ & $12,100 \mathrm{mg} / \mathrm{m}^{3}$ & $3-18 \mathrm{mg} / \mathrm{m}^{3}$ & $873,000 \mathrm{mg} / \mathrm{m}^{3}$ & $3,300,000 \mathrm{mg} / \mathrm{m}^{8}$ & $6,370,000 \mathrm{mg} / \mathrm{m}^{3}$ & $630 \mathrm{mg} / \mathrm{m}^{3}$ & Negligible \\
\hline $\begin{array}{l}\text { State } \\
\left(20^{\circ} \mathrm{C}\right)\end{array}$ & Liquid & Liquid & Liquilt & Vapour & Vapour & Liquid & solid \\
\hline $\begin{array}{l}\text { Duration } \\
\text { of hazard } \\
\text { Casualty }\end{array}$ & $\frac{1}{4}-4 \mathrm{~h}$ & $3-21$ days & Few minutes & Few minutes & Few minutes & $2-7$ days & - \\
\hline $\begin{array}{l}\text { Casualty } \\
\text { dosage }\end{array}$ & $>5 \mathrm{mg} \mathrm{min} / \mathrm{m}^{3}$ & $>0.5 \mathrm{mg} \mathrm{min} / \mathrm{m}^{3}$ & $>2,000 \mathrm{mg} \mathrm{min} / \mathrm{m}^{3}$ & $>7,000 \mathrm{mg} \mathrm{min} / \mathrm{m}^{3}$ & $>1,600 \mathrm{mg} \mathrm{min} / \mathrm{m}^{3}$ & $>100 \mathrm{mg} \mathrm{min} / \mathrm{m}^{3}$ & $0 \cdot 001 \mathrm{mg}$ (oral) \\
\hline LCt $_{5 n}$ & $100 \mathrm{mg} \mathrm{min} / \mathrm{m}^{3}$ & $10 \mathrm{mg} \mathrm{min} / \mathrm{m}^{3}$ & $5,000 \mathrm{mg} \mathrm{min} / \mathrm{m}^{3}$ & $11,000 \mathrm{mg} \min / \mathrm{m}^{3}$ & $3,200 \mathrm{mg} \mathrm{min} / \mathrm{m}^{3}$ & $1,500 \mathrm{mg} \mathrm{min} / \mathrm{m}^{3}$ & $0 \cdot 0 \cdot 2 \mathrm{mg}$ min $\mathrm{m}^{3}$ \\
\hline
\end{tabular}

concentrations as low as a few milligrams per cubic metre so long as the exposure is long enough. Botulinin toxin is quoted as the most powerful natural poison.

The committee has made a careful study of the possible effects of an attack with lethal agents on human populations. The spread of agents in the form of vapour or a cloud of aerosol-the pattern of the distribution of the material would resemble the familiar pattern of the spread of fallout from a nuclear explosion. As with nuclear weapons, more concentrated bursts produced by the impact of shells would lead to less elongated distribution. One of the particular tactical advantages of chemical and biological weapons is that it should be possible to release them along a linear pattern and thus more carefully than with radioactive fallout to control the pattern in which they spread.

For action against protected troops, it would be necessary to distribute something between a tenth and 10 grams of liquid nerve gas per square metre. Obviously such an attack would not be a casual undertaking. Such an attack would also spread aerosol in the surrounding area and lethal effects would occur wherever the dosage was greater than $80 \mathrm{mg} \mathrm{min} / \mathrm{m}^{3}$. This would imply casualties within some tens of kilometres of a military target. In attacks against populated cities, surprise would be important, but, given luck, in this sense, it should be possible to disable half the population, killing a quarter of it. Of the biological agents which the committee has considered, anthrax, plague, Q fever, cholera and yellow fever are singled out. Aerosols are considered to be the most likely means of distribution, presumably sprayed from aircraft. With these devices, a single aircraft could produce an aerosol line source 100 kilometres long and thus ensure that some 50 per cent of the population in 5,000 square kilometres downwind would be affected. In this spirit, the committee goes on to calculate a comparison between the effects of a one megaton nuclear attack, a chemical attack with 15 tons of nerve agents and a biological attack with 10 tons of a culture laden with microorganisms. Some of the results are shown in Table 2.

In the use of these materials, much will depend on environmental factors, especially the weather. The objective would be to create an infectious acrosol which would be an inhalation hazard. The viability of organisms would depend on atmospheric factors such as temperature and humidity, but it is known that some materials used in agricultural applications decay at a rate of 5 per cent a minute.

of the long-term effects of ehemical and biological warfare, the committee says that the ecological consequences of the use of these materials could be permanent. The organophosphorus nerve agents, for example, could kill all forms of animal life and thus seriously disturb the natural balance. The committee has nothing specific to say about the use of herbicides in South Vietnam (16 per cent of the forested area of which has so far been treated), but it does say that birds have migrated from some of the areas attacked and that experience there has shown that regenerated forest has in the past been associated with the appearance of scrub typhus.

Table 2. COMPARATIVE ESTIMATES OF DISABLING EFFECTS OF HYPOTHETICAL ATTACKS ON TOTALLY UNPROTECTED POPULATIONS ISINi A NLCLEAR, CHEMICAL OR BACTERIOLOGICAL (BIOLOGICAL) WEAPON THAT COLID BE CARRIED BY A SINGLE STRATEGIC BOMBER

Criterion for estimate

Area affected

Time delay before onset of effert Damage to structures

Other effects Possibility of later normal use of
affected areal after attack

Maximum effect on man

Multi-year investment in substantial research and development production capability ${ }^{\dagger}$

$\begin{gathered}\text { Nuclear } \\ \text { (one megaton) }\end{gathered}$
Up to $300 \mathrm{~km}^{2}$
Seconds
Destruction over an area of 100
$\mathrm{~km}^{2}$
Radioactive contamination in an
area of $2,500 \mathrm{~km}^{2}$ for $3-6$ months
$3-6$ months after attack
90 per cent deaths

$\$ 5,000-\$ 10,000$ million Type of weapon Chemical
(15 tons of nerve agent)

Ip to $60 \mathrm{~km}^{2}$

Minutes

None

Contamination by persistence of agent from a few days to weeks Limited during period of contamination

50 per cent deaths

$\$ 1,000-\$ 5,000$ million
Bacteriological (biological) (10 tons*)

Vp to $100,000 \mathrm{~km}^{2}$

Days

None

Possible cpidemic or establishment of new endemic foci of disease

After end of incubation period or subsidence of epidemic

50 per cent morbidity: $25 \mathrm{per}$ cent deaths if no medical interven-

$\$ 1,000-\$ 5,000$ million

* $\dagger$ It is assumed that indieated eumulative investments in research and development and production plants
stantial independent capability. Individual weapons could be fabricated without making this total investment. 